\title{
Assessment of the interaction between straw size and thawing rate and its impact on in vitro quality of post-thaw goat semen ${ }^{1}$
}

\author{
Francisco Silvestre Brilhante Bezerra², Thibério de Souza Castelo², Érika Aparecida Araújo \\ dos Santos ${ }^{2}$, Tiago da Costa Dantas², Bruno Rodrigo Simão², Alexandre Rodrigues Silva ${ }^{2}$ \\ ${ }^{1}$ Financial support provided by Banco do Nordeste (BnB). \\ 2 Laboratório de Conservação de Germoplasma Animal, Universidade Federal Rural do Semi-Árido - UFERSA, BR 110, Km 47, Costa e Silva, \\ 59625-900, Mossoró, RN, Brazil.
}

\begin{abstract}
The objective of this study was to analyze interactions between different straw sizes and thawing rates on the post-thaw goat semen parameters. Twenty-one ejaculates (seven per animal) were collected from three stud bucks by using an artificial vagina. After evaluation, the semen was extended in Tris-egg yolk-glycerol and packed in 0.25 and $0.50 \mathrm{~mL}$ straws, followed by storage in liquid nitrogen. Thawing was performed using two different rates: $37{ }^{\circ} \mathrm{C} / 1 \mathrm{~min}$ and $55{ }^{\circ} \mathrm{C} / 7 \mathrm{~s}$. The interaction between the $0.5-\mathrm{mL}$ straw and the thawing rate of $55^{\circ} \mathrm{C} / 7 \mathrm{~s}$ promoted higher progressive motility. When the effect of straws alone was analyzed, it was verified that the use of the $0.50 \mathrm{~mL}$ straw promoted better conservation than the $0.25 \mathrm{~mL}$ one for progressive motility and acrosomal integrity, after the frozen-thawing procedures. Optimal results for progressive motility were achieved when goat semen was frozen in $0.5 \mathrm{~mL}$ straws and thawed in water at $55{ }^{\circ} \mathrm{C} / 7 \mathrm{~s}$.
\end{abstract}

Key Words: Capra hircus, cryopreservation, semen processing

\section{Introduction}

Cryopreservation as a technique for goat semen storage supports a genome resource bank for an indeterminate period of time. Nevertheless, freezing and thawing induce detrimental effects on the ultra-structure, biochemistry, and functional integrity of the sperm (Watson, 2000), resulting in a reduction of motility, membrane integrity and fertilizing ability (Purdy, 2006). Many factors, such as freezing rate (Chemineau et al., 1991), extender (Hashemi et al., 2007), cryoprotectant (Lopes et al., 2009), dilution rate (Evans \& Maxwell, 1987; Ritar et al., 1990a) and packaging method (Maxwell et al., 1995; Paulenz et al., 2004) affect the quality of frozen-thawed semen from different species. However, for goats, packaging in 0.25 and $0.5 \mathrm{~mL}$ French plastic straws does not seem to affect sperm motility (Ritar et al., 1990b).

Thawing rate is another important factor that affects semen quality parameters (Tuli et al., 1991). Traditionally, straws containing goat semen are thawed at $37^{\circ} \mathrm{C}$ in a water bath for 12-30 s (Watson, 2000; Cabrera et al., 2005), but another slow protocol $\left(5{ }^{\circ} \mathrm{C} / 2 \mathrm{~min}\right.$ in water bath) was demonstrated with lesser efficiency (Deka \& Rao, 1987). Tuli et al. (1991) observed significantly higher progressive motility on goat semen thawed at $70^{\circ} \mathrm{C} / 7 \mathrm{~s}$, compared with the thawing rates of $37^{\circ} \mathrm{C} / 2 \mathrm{~min}$ or $40^{\circ} \mathrm{C} / 20 \mathrm{~s}$.
Many studies have been conduced to assess the influence of different packaging methods on sperm survival, using different thawing procedures for boars (Eriksson \& Rodriguez-Martinez, 2000), fish (Richardson et al., 2000), rams (Paulenz et al., 2004), and dogs (Nöthling \& Shuttleworth, 2005). For goats, however, the majority of the studies report the effect of different thawing rates or packaging methods solely and there is a lack of information regarding a possible interaction between these factors. This interaction could increase the survival rate of sperm after thawing as well as the efficiency of goat semen cryopreservation. Therefore, the objective of this study is to investigate the interactions between straws of different sizes and different thawing rates and their impact on the post-thaw goat semen parameters.

\section{Material and Methods}

Experimental protocols and animal care were approved by the research committee of the Universidade Federal Rural do Semi-Árido (UFERSA), Mossoró, Brazil. Semen was collected from three bucks, one Savannah and two Boer. They were healthy and sexually mature, aging approximately two years. Goats were raised on a farm located in the rural area of Mossoró $\left(5^{\circ} 11^{\prime} \mathrm{S}, 37^{\circ} \mathrm{W}\right.$, and an altitude of $16 \mathrm{~m}$ ), northeast Brazil, and maintained under 
extensive management with free access to the native vegetation, without restrictions of feed and water. However, two days before the semen collection, animals were housed in a common covered shelter, separated from females. The experiment was conducted from May to July 2009.

One month before starting the experiments, all the males were trained for semen collection in an artificial vagina $\left(43^{\circ} \mathrm{C}\right)$ connected to a glass graduated tube using an induced-estrus doe as a teaser (Silvestre et al., 2004). Semen was collected from each buck twice a week. Immediately after collection, the ejaculates were maintained immersed in a warm water bath at $37^{\circ} \mathrm{C}$ until their assessment. Semen assessment was performed within approximately 15 min, and only those semen samples presenting at least $80 \%$ spermatozoa showing individual progressive motility were selected for freezing. A total of 21 ejaculates (seven per animal) were used in this experiment.

Color, aspect and volume were evaluated in the fresh semen. Microscopic criteria such as sperm progressive motility (\%) and mass activity ( $0-5$ scale) were subjectively analyzed by light microscopy (Nikon, Eclipse E200, Tokyo, Japan) under 100x magnification. All the samples were evaluated by the same operator. Percentage of live spermatozoa was established by analyzing a slide stained with Brome-phenol Blue under light microscopy (400×), counting 200 cells per slide (Derivaux et al., 1980). Following the initial assessment, a $10-\mu \mathrm{L}$ semen aliquot was diluted in $2 \mathrm{~mL}$ of buffered formalin (10\%), and the sperm concentration (sperm $\times 10^{6} \mathrm{~mL}^{-1}$ ) was determined using a Neubauer counting chamber. For sperm morphology evaluation, 200 sperm cells from random fields were analyzed in Bengal Rose smears by light microscopy, under 1000x magnification . The total sperm defects were counted in 200 cells, in which acrosomal integrity was also evaluated (Njenga et al., 1999). For the evaluation of sperm membrane integrity, a hypoosmotic swelling test (HOST) was performed immediately after the collection of semen, using a sodium citrate and fructose hypo-osmotic solution (100 mOsm/L). A total of 200 spermatozoa were counted using a phase-contrast microscope at 400x magnification, and spermatozoa with swollen coiled tails were considered as presenting a functional sperm membrane (Fonseca et al., 2005).

An extender consisting of $3.028 \mathrm{~g}$ Tris-hydroxymethylaminomethane, $1.78 \mathrm{~g}$ monohydrated citric acid and $1.25 \mathrm{~g}$ D-fructose dissolved in $100 \mathrm{~mL}$ of distilled water was used (Siqueira et al., 2009). The osmotic pressure of this solution was $295 \mathrm{mOsm} / \mathrm{L}$ and the $\mathrm{pH}, 6.6$. Two-and-a-half percent of this solution was subsequently replaced by egg-yolk.

Semen was initially extended in Tris-egg yolk at room temperature $\left(32^{\circ} \mathrm{C}\right)$. Samples were kept in an isothermal box and transported to the laboratory. After $40 \mathrm{~min}$, the temperature in the isothermal box reached $15^{\circ} \mathrm{C}\left(-0.30^{\circ} \mathrm{C} / \mathrm{min}\right)$, and the samples were transferred to a refrigerator for 30 more minutes, where they reached $4^{\circ} \mathrm{C}$ at $0.37^{\circ} \mathrm{C} / \mathrm{min}$. After cooling, the semen was added to Tris-egg yolk plus glycerol in a final concentration of $6 \%$. Final dilution resulted in a sperm concentration of $150 \times 10^{6} \mathrm{sperm} / \mathrm{mL}$. Each sample was packed into previously marked $0.5(\mathrm{n}=4)$ and $0.25 \mathrm{~mL}$ $(\mathrm{n}=4)$ plastic straws, which were placed horizontally in a thermal box for 5 min, $5 \mathrm{~cm}$ above the liquid nitrogen $\left(\mathrm{N}_{2}\right)$ level, reaching a temperature close to $-70^{\circ} \mathrm{C}$ in the vapor. Finally, the straws were plunged into liquid nitrogen for storage up to the thawing moment (Sundararaman \& Edwin, 2008).

The straws were removed from the liquid nitrogen and randomly thawed seven days after freezing. A couple of straws (one of 0.5 and another of $0.25 \mathrm{~mL}$ ) of each sample were thawed on a water bath at $37^{\circ} \mathrm{C} / 1 \mathrm{~min}$, and other pair from the same sample on a water bath at $55^{\circ} \mathrm{C} / 7 \mathrm{~s}$, following another $30 \mathrm{~s}$ at $37^{\circ} \mathrm{C}$. Finally, straws were removed and dried, the plug was cut off, and the contents pushed out into a glass vial that was in a water bath at $37^{\circ} \mathrm{C}$. The semen samples were immediately evaluated for sperm progressive motility, live sperms, morphology, and acrosomal and membrane integrity as previously described.

For statistical analysis, 21 replicates were performed for each treatment. The results were expressed as mean \pm SEM (standard error of the mean) and evaluated through the SAS (Statistical Analysis System, version 6.10), Percentage data were ArcSin transformed. To evaluate the effect of different factors and their interactions on the variables considered in this study, the data were subjected to the analysis of variance using the General Linear Model procedure (GLM). The Friedman test was applied to evaluate differences between different treatments (straw size $x$ thawing temperature) with regard to sperm characteristics, except for sperm motility, which was evaluated by KruskalWallis test. For all statistical analysis, significance was established at $\mathrm{P}<0.05$.

\section{Results and Discussion}

Fresh goat semen was yellowish in color and milky in aspect. The total volume of ejaculates was $1.1 \pm 0.4 \mathrm{~mL}$, with a sperm concentration of $2.4 \pm 1.0 \times 10^{9}$ spermatozoa $/ \mathrm{mL}$. Sperm progressive motility of fresh semen was $94.9 \pm 1.7 \%$, and mass activity was $3.9 \pm 0.1$. Percentage of live sperm was $92.7 \pm 2.0 \%$ and sperm with normal morphology was $76.2 \pm 1.8 \%$, in which $99.8 \pm 0.1 \%$ spermatozoa presented intact acrosome. These findings are considered within the normal range for goat species, according to Salviano \& Souza (2008). 
A total of $30.8 \pm 2.0 \%$ sperms with functional membrane integrity were found in the HOST for fresh semen, which demonstrates that membrane damage still exists in the beginning of the experiment. It is important to emphasize that the animals were raised under extensive management in a tropical area, and hence, under thermal stress. The high temperatures found in the low latitudes affect the sperm quality and production in ruminants (Entwistle, 1992). Thermal stress is associated with oxidative stress and the generation of reactive oxygen species (ROS), responsible for the loss of membrane integrity, impaired cell function and decreased motility of the sperm. For goats, the ratio of unsaturated to saturated fatty acids in the sperm membranes is higher than in other species, making the membranes more susceptible to peroxidative damage in the presence of ROS (Bucak et al., 2009). These facts were probably associated to the low values found for HOST in fresh semen.

Extended semen presented $93.8 \pm 1.7 \%$ of progressive motile sperm, while after the cooling process and addition of glycerol, semen showed a significant reduction of this parameter to $70.5 \pm 1.7 \%(\mathrm{P}<0.05)$. It is clear that chilling reduces the motility of the sperm, whereas glycerol induces osmotic and structural damages in the sperm, which results in reduction of goat semen kinematic parameters (Sundararaman \& Edwin, 2008).
The cryopreservative process greatly affected $(\mathrm{P}<0.05)$ sperm progressive motility and the percentage of live spermatozoa (Table 1). As related before, both thermal stress and the cryopreservation process cause changes in the membrane integrity, and the Brome-phenol Blue staining technique is based on the permeability of the membrane. Cryopreservation still causes phase transitions of the lipids in the membrane of spermatozoa (Woelders, 1997). This vulnerability is due to lipids and proteins in the membrane that are not covalently linked and can move easily (Parks \& Graham, 1992).

Although a significant decrease $(\mathrm{P}<0.05)$ was found for membrane integrity after the cryopreservation process, it was clearly demonstrated that these values after thawing became closer than those found in fresh semen. It must be emphasized that the semen had already been damaged before the cryopreservation process, as demonstrated by the low membrane integrity percentages in fresh semen. It is known that frozen-thawed sperm were mobile but damaged because the plasma membrane is more sensitive than the nucleus and locomotor (mid-piece) parts of the cell, a finding in agreement with previous studies (Salamon \& Maxwell,1995; Celeghini et al., 2008).Therefore, after thawing, with the addition of cryoinjuries, a great number of spermatozoa died (Salamon \& Maxwell, 1995). These data

Table 1 - Mean values ( \pm SEM) for characteristics of frozen goat semen packed into 0.25 or $0.50 \mathrm{~mL}$ straws and thawed at $37^{\circ} \mathrm{C} / 1 \mathrm{~min}$ or $55^{\circ} \mathrm{C} / 7 \mathrm{~s}(\mathrm{n}=21)$

\begin{tabular}{|c|c|c|c|c|c|}
\hline \multirow[t]{2}{*}{ Sperm parameter } & \multirow[t]{2}{*}{ Fresh semen } & \multicolumn{2}{|c|}{$0.25 \mathrm{~mL}$} & \multicolumn{2}{|c|}{$0.50 \mathrm{~mL}$} \\
\hline & & $37{ }^{\circ} \mathrm{C} / 1 \mathrm{~min}$ & $55^{\circ} \mathrm{C} / 7 \mathrm{~s}$ & $37{ }^{\circ} \mathrm{C} / 1 \mathrm{~min}$ & $55^{\circ} \mathrm{C} / 7 \mathrm{~s}$ \\
\hline Progressive motility (\%) & $94.9 \pm 1.7 \mathrm{a}$ & $32.2 \pm 2.1 b c$ & $30.4 \pm 2.2 c$ & $36.3 \pm 2.1 b c$ & $37.2 \pm 2.2 b$ \\
\hline Live sperm (\%) & $92.7 \pm 2.0 \mathrm{a}$ & $16.2 \pm 1.9 b$ & $17.2 \pm 2.0 \mathrm{~b}$ & $15.2 \pm 1.9 b$ & $15.6 \pm 2.0 \mathrm{~b}$ \\
\hline Membrane integrity (\%) & $30.8 \pm 2.0 \mathrm{a}$ & $22.8 \pm 1.9 b$ & $21.6 \pm 2.0 \mathrm{~b}$ & $23.4 \pm 1.9 b$ & $24.1 \pm 2.0 b$ \\
\hline Normal sperm (\%) & $76.2 \pm 1.8 \mathrm{a}$ & $62.4 \pm 1.4 b$ & $65.4 \pm 1.4 b$ & $60.9 \pm 1.4 \mathrm{~b}$ & $63.4 \pm 1.4 b$ \\
\hline Total defects (\%) & $23.9 \pm 1.7 a$ & $37.6 \pm 1.4 b$ & $34.6 \pm 1.4 b$ & $39.1 \pm 1.4 b$ & $36.6 \pm 1.4 b$ \\
\hline Acrosomal integrity (\%) & $99.8 \pm 0.1 \mathrm{a}$ & $99.4 \pm 0.1 \mathrm{a}$ & $99.4 \pm 0.1 \mathrm{a}$ & $99.7 \pm 0.1 \mathrm{a}$ & $99.5 \pm 0.1 \mathrm{a}$ \\
\hline
\end{tabular}

a,b Within a row, values with different superscripts differ $(\mathrm{P}<0.05)$.

SEM - standard error of the mean.

Table 2 - Mean values ( \pm SEM) for frozen-thawed goat sperm characteristics comparing the effect of thawing rate and straw size separately $(\mathrm{n}=21)$

\begin{tabular}{|c|c|c|c|c|}
\hline \multirow[t]{2}{*}{ Seminal parameters } & \multicolumn{2}{|c|}{ Thawing rate* } & \multicolumn{2}{|c|}{ Straw size } \\
\hline & $37{ }^{\circ} \mathrm{C} / 1 \mathrm{~min}$ & $55^{\circ} \mathrm{C} / 7 \mathrm{~s}$ & $0 ., 25 \mathrm{~mL}$ & $0.50 \mathrm{~mL}$ \\
\hline Progressive motility (\%) & $34.3 \pm 1.4$ & $34.1 \pm 1.5$ & $31.4 \pm 1.5 b$ & $36.9 \pm 1.4 \mathrm{a}$ \\
\hline Live sperm (\%) & $16.0 \pm 1.4$ & $17.0 \pm 1.5$ & $17.1 \pm 1.5 a$ & $15.9 \pm 1.4 \mathrm{a}$ \\
\hline Membrane integrity (\%) & $23.2 \pm 1.3$ & $22.7 \pm 1.3$ & $22.4 \pm 1.3 a$ & $23.5 \pm 1.3 a$ \\
\hline Normal sperm (\%) & $61.6 \pm 0.1$ & $64.2 \pm 1.0$ & $63.7 \pm 1.0 \mathrm{a}$ & $62.1 \pm 1.0 \mathrm{a}$ \\
\hline Total defect (\%) & $38.4 \pm 0.1$ & $35.8 \pm 1.0$ & $36.3 \pm 1.0 \mathrm{a}$ & $37.9 \pm 1.0 \mathrm{a}$ \\
\hline Acrosomal integrity (\%) & $99.6 \pm 0.1$ & $99.4 \pm 0.1$ & $99.4 \pm 0.1 b$ & $99.6 \pm 0.1 \mathrm{a}$ \\
\hline
\end{tabular}

${ }^{*}$ No differences $(\mathrm{P}>0.05)$ were observed between thawing rates.

a,b Within a row, values with different superscripts differ $(\mathrm{P}<0.05)$

SEM - standard error of the mean. 
suggest that membrane integrity can be as important as motility to predict the fertility rates.

The packaging of goat semen made in a $0.5 \mathrm{~mL}$ straw in association with the thawing rate performed at $55{ }^{\circ} \mathrm{C} / 7 \mathrm{~s}$ promoted higher progressive motility $(\mathrm{P}>0.05)$. These results agree with those found for dogs, in which an interaction between $0.5 \mathrm{~mL}$ straw with a thawing rate performed with high temperature $\left(70^{\circ} \mathrm{C} / 5 \mathrm{~s}\right)$ promoted the best post-thaw semen quality (Nöthling \& Shuttleworth, 2005).

In spite of the better interaction between the $0.5 \mathrm{~mL}$ straw and the thawing at $55^{\circ} \mathrm{C} / 7 \mathrm{~s}$, when data were grouped to assess the isolated effect of thawing rates or straws, no differences were verified between thawing performed at $37^{\circ} \mathrm{C} / 1 \mathrm{~min}$ and at $55^{\circ} \mathrm{C} / 7 \mathrm{~s}$ for all assessed parameters (Table 2). Despite these results, Lahnsteiner (2000) related thawing rate as the most sensitive parameter during semen cryopreservation. This author recommended performing the thawing at high temperatures in order to avoid recrystallization, because the warming damage occurs when the spermatozoa pass through the critical zone of -50 through $-15^{\circ} \mathrm{C}$ or $-5^{\circ} \mathrm{C}$. Similarly, spermatozoa suffer osmotic stress, when the duration of thawing is insufficient for the outflow of excess cryoprotectants from the cell and the spermatozoa swells and lyses as the medium dilutes abruptly on account of melting of the extracellular ice (Andrabi, 2007).

Thawing rates used in the present study do not seem to be different in promoting spermatozoa damages, probably because $37{ }^{\circ} \mathrm{C} / 1 \mathrm{~min}$ and $55^{\circ} \mathrm{C} / 7 \mathrm{~s}$ for goat semen do not produce sufficient differences in the amount of large ice crystals formed during recrystallization, which are very deleterious for spermatic cells. In fact, for goat semen, different temperatures have been used in protocols of thawing by different authors (Tuli et al., 1991; Deka \& Rao, 1987; Khalifa \& El-Saidy, 2008; Sundararaman \& Edwin, 2008). On the other hand, studies have demonstrated that a fast thawing rate results in better post-thaw quality when compared with slower thawing for stallions, rams (Watson, 1990), bulls (Pace et al., 1981), boars (Eriksson \& RodriguezMartinez, 2000) and dogs (Nöthling \& Shuttleworth, 2005). However, there is a plateau in the relation between thawing rate and sperm survival; nevertheless, by increasing the temperature from 50 to $70{ }^{\circ} \mathrm{C}$, sperm motility could not be further improved (Woelders \& Malva, 1998). The authors of the present study hypothesize that a plateau from $37^{\circ} \mathrm{C}$ to $55^{\circ} \mathrm{C}$ would not affect the semen quality of the goats either. However, attention to temperature and timing becomes much more critical at temperatures greater than $37^{\circ} \mathrm{C}$, as these high temperatures can result in sperm mortality if performed improperly. Thus, thawing semen at $37^{\circ} \mathrm{C}$ is more suitable under practical conditions of artificial insemination and the risk of overheating the thawed semen is also lower.

Otherwise, when the effect of straw size was compared alone, sperm progressive motility and acrosomal integrity was significantly better preserved with the use of $0.5 \mathrm{~mL}$ straws (Table 2). The surface-to-volume ratio of the package has important implications for the cooling, freezing, and thawing rates of semen. Semen packaging is also important for practical reasons, as it determines both the means of identification of each dose of semen and how it may be arranged for storage in the liquid nitrogen container (Maxwell et al., 1995).

The pattern of cooling and initiation of ice crystallization depends, among other factors, on the straw size. The $0.25 \mathrm{~mL}$ straw has a higher surface-to-volume ratio than the $0.50 \mathrm{~mL}$ one, which increases the opportunity for post-thaw temperature changes of the semen within the straw. Such changes can compromise the post-thaw recovery of live spermatozoa and thus decrease fertility (Johnson et al, 1995).

Different lipids have different phase transition temperatures and some types of lipid aggregates in domains of gel-like (frozen) lipids, thus excluding other lipid types that remain in the liquid-crystalline (melted) state (Woelders, 1997; Medeiros et al, 2002). In the cryopreservation process, membrane proteins are also excluded from these gel domains and consequently find themselves in a non-physiological lipid environment (Medeiros et al, 2002). This is believed to impair the function of membrane proteins that are necessary for structural integrity or ion metabolism (Watson, 2000), which was also probably associated to the lower preservation of the progressive motility and acrosomal integrity with the $0.25 \mathrm{~mL}$ straw use as observed in the present study.

The results in this study disagree with a previous study (Ritar et al., 1990b), which concluded that there is no difference between goat sperm frozen in 0.25 (33\% postthaw motility) and $0.50 \mathrm{~mL}$ straws (34\% post-thaw motility). In addition, bull semen packaged in 0.25 and $0.50 \mathrm{~mL}$ straws containing $10 \times 10^{6}$ total spermatozoa/straw and thawed at $37^{\circ} \mathrm{C} / 30 \mathrm{~s}$ in both cases, provided similar conception rates (Johnson et al., 1995).

Numerical differences found for progressive motility after thawing between 0.25 and 0.5 -mL straws in the present research were really low, and probably, there are few biological implications on total fertility. Furthermore, the dilution rate was exactly the same for both groups $\left(150 \times 10^{6}\right.$ sperm $/ \mathrm{mL}$ ), which determined an equal proportion of extender and sperms for all the treatments. 


\section{Conclusions}

It is recommended that goat semen be frozen in $0.5 \mathrm{~mL}$ straws and thawed in water at $55^{\circ} \mathrm{C} / 7 \mathrm{~s}$.

\section{Acknowledgments}

The authors express their gratitude to people from Frei Damião Farm for their inestimable help at the fieldwork, and to Bank of Northeast, Brazil (BNB) for the financial support.

\section{References}

ANDRABI, S.M.H. Fundamental principles of cryopreservation of Bos taurus and Bos indicus bull spermatozoa. International Journal of Agriculture and Biology, v.9, n.2, p.367-369, 2007.

BUCAK, M.N.; SARIÖZKAN, S.; TUNCER, P.B. et al. Effect of antioxidants on microscopic semen parameters, lipid peroxidation and antioxidant activities in Angora goat semen following cryopreservation. Small Ruminant Research, v.81, p.90-95, 2009.

CABRERA, F.; GONZÁLEZ, F.; BATISTA, M. et al. The effect of removal of seminal plasma, egg yolk level and season of sperm freezability of canary Buck (Capra hircus). Reproduction in Domestic Animals, v.40, n.3, p.191-195, 2005.

CELEGHINI, E.C.C.; ARRUDA, R.P.; ANDRADE, A.F.C. et al. Effects that bovine sperm cryopreservation using two diferente extenders has on sperm membranes and chromatin. Animal Reproduction Science, v.104, p.119-131, 2008.

CHEMINEAU, P.; CAGNIE, Y.; GUERIN, Y. et al. Training manual on artiûcial insemination in sheep and goats. Rome: FAO Reproduction and Health Paper. Food and Agriculture Organization of the United Nations, 1991. p.115-161.

DEKA, B.B.; RAO, A.R. Effect of extenders and thawing methods on post-thawing preservation of goat semen. Indian Veterinary Journal, v.64, p.591-594, 1987.

DERIVAUX, J. Reprodução dos animais domésticos. Zaragoza: Acribia, 1980. 446p.

ENTWISTLE, K. Effects of heat stress on reproductive function in bulls. Bull Fertility, Proceedings... p.57-63, 1992.

ERIKSSON, B.M.; RODRIGUEZ-MARTINEZ, H. Effect of freezing and thawing rates on the post-thaw viability of boar spermatozoa frozen in FlatPacks and Maxi-straws. Animal Reproduction Science, v.63, n.3-4, p.205-220, 2000.

EVANS, G.; MAXWELL, W.M.C. Frozen storage of semen. In: Salamon's artificial insemination of sheep and goats. Wellington, New Zealand: Butter-worths, 1987. p.122-154.

FONSECA, J.F.; TORRES, C.A.A.; MAFFILI, V.V. et al. The hypoosmotic swelling test in fresh goat spermatozoa. Animal Reproduction, v.2, n.2, p.139-144, 2005.

HASHEMI, A.; FARHOOMAND, P.; PIRMOHAMMADI, R. et al. Effect of extender and thawing methods on post thawing preservation. Journal of Animal and Veterinary Advances, v.6, n.11, p.1337-1339, 2007.

JOHNSON, M.S.; SENGER, P.L.; ALLEN, C.H. et al. Fertility of bull semen packaged in .25 and .5-milliliter French straws. Journal of Animal Science, v.73, n.7, p.1914-1919, 1995.

KHALIFA, T.A.A.; EL-SAIDY, B.E. Testing usability of butylated hydroxytoluene in conservation of goat semen. Reproduction in Domestic Animals, v.43, n.5, p.525-530, 2008.

LAHNSTEINER, F. Semen cryopreservation in the salmonidae and in the northern pike. Aquaculture Research v.31, n.3, p.245-258, 2000 .
LOPES, K.R.F.; COSTA, L.L.M.; LIMA, G.L. et al. Dimethylformamide is no better than glycerol for cryopreservation of canine semen. Theriogenology, v.72, n.5, p.650-644, 2009.

MAXWELL, W.M.C.; LANDERS, A.J.; EVANS, G. Survival and fertility of ram spermatozoa frozen in pellets, straws and minitubes. Theriogenology, v.43, n.7, p.1202-1210, 1995.

MEDEIROS, C.M.O; FORELL, F.; OLIVEIRA, A.T.D. et al. Current status of sperm cryopreservation: why isn't it better? Theriogenology, v.57, n.1, p.327-44, 2002.

NJENGA, M.J.; MUNYUA, S.J.M.; MUTIGA, E.R. et al. Semen characteristics of goats with subacute, acute and chronic besnoitiosis: research communication. Journal of the South African Veterinary Association, v.70, n.1, p.18-20, 1999.

NÖTHLING, J.O.; SHUTTLEWORTH, R. The effect of straw size, freezing rate and thawing rate upon post-thaw quality of dog semen. Theriogenology, v.63, n.5, p.1469-1480, 2005.

PACE, M.M.; SULLIVAN, J.J.; ELLIOTT, F.I. et al. Effects of thawing temperature, number of spermatozoa and spermatozoa quality on fertility of bovine spermatozoa packaged in $.5 \mathrm{~mL}$ French straws. Journal of Animal Science, v.53, p.693-701, 1981.

PARKS, J.E.; GRAHAM, J.K. Effects of cryopreservation procedures on sperm membranes. Theriogenology, v.38, n.2, p.209-222, 1992.

PAULENZ, H.; SÖDERQUIST, L.; ÅDNØY, T. et al. Fertility results after different thawing procedures for ram semen frozen in minitubes and mini straws. Theriogenology, v.61, n.9, p.1719-1727, 2004.

PURDY, P.H. A review on goat sperm cryopreservation. Small Ruminant Research, v.63, n.3, p.215-225, 2006.

RICHARDSON, G.F.; MILLER, T.I.; MCNIVEN, M.A. Cryopreservation of Arctic charr, Salvelinus alpinus (L.), semen in various extenders and in three sizes of straw. Aquaculture Research, v.31, n.3, p.307-315, 2000

RITAR, A.J.; BALL, P.D.; O’MAY, P.J. Artificial insemination of Cashmere goats: effects on fertility and fecundity of intravaginal treatment, method and time of insemination, semen freezing process, number of motile spermatozoa and age of females. Reproduction, Fertility and Development, v.2, n.4, p.377-384, 1990a.

RITAR, A. J.; BALL, P. D.; O’MAY, P. J. Examination of methods for the deep freezing of goat semen. Reproduction, Fertility and Development, v.2, n.1, p.27-34, 1990b.

SALAMON, S.; MAXWELL, W.M.C. Frozen storage of ram semen II. Causes of low fertility after cervical insemination and methods of improvement. Animal Reproduction Science, v.38, p.1-16, 1995.

SALVIANO, M.B.; SOUZA, J.A.T. Avaliação andrológica e tecnologia do sêmen caprino. Revista Brasileira de Reprodução Animal, v.12, n.3, p.159-167, 2008.

SILVESTRE, M.A.; SALVADOR, I.; SÁNCHEZ, J.P. et al. Effect of changing female stimulus on intensive semen collection in young Murciano-Granadina male goats. Journal of Animal Science, v.82, p.1641-1645, 2004.

SIQUEIRA, A.P.; SILVA FILHO, J.M.; FONSECA, J.F. et al. Taxa de concepção de cabras inseminadas com sêmen caprino resfriado a $5^{\circ} \mathrm{C}$, por 12 ou 24 horas, em meio diluidor à base de gema de ovo. Arquivo Brasileiro de Medicina Veterinária e Zootecnia, v.61, n.1, p.66-71, 2009.

SUNDARARAMAN, M.N.; EDWIN, M.J. Changes in motility characteristics of goat spermatozoa during glycerol-equilibration and the relevance to cryopreservation. Asian Journal of Cell Biology, v.3, n.1, p.22-23, 2008.

TULI, R.K.; SCHMIDT-BAULAIN, R.; HOLTZ, W. Influence of thawing temperature on viability and release of glutamic oxaloacetic transaminase in frozen semen from Boer goats. Animal Reproduction Science, v.25, n.2, p.125-131, 1991. 
WATSON, P.F. Artificial insemination and the preservation of semen. In: LAMMING, G. (Ed.). Marshall's physiology of reproduction, Edinburgh: Churchill Livingstone, 1990. p.747869.

WATSON, P.F. The causes of reduced fertility with cryopreserved semen. Animal Reproduction Science, v.60-61, p.481-492, 2000 .
WOELDERS, H. Fundamentals and recent development in cryopreservation of bull and boar semen. Veterinary Quarterly, v.19, n.3, p.135-138, 1997.

WOELDERS, H.; MALVA, A.P. How important is the cooling rate in cryopreservation of (bull) semen, and what is its relation to thawing rate and glycerol concentration. Reproduction in Domestic Animals, v.33, n.3-4, p.299-305, 1998. 